\title{
KOMISI YUDISIAL DAN PENGAWASAN HAKIM DI INDONESIA
}

\section{Wahyu Wiriadinata ${ }^{1}$}

This paper to determine the effectiveness of the Judicial Commission under the supervision of judges in Indonesia and the cause of it. Enforcement cases judges who violate the code of conduct of judges as well as breaking the law has become a current phenomenon. The method used in this paper is "normative legal research/normative, the data were analyzed descriptively qualitative. Descriptive qualitative analysis is a method of data analysis to categorize and select primary data in the form of legislation, then connected with the theories, principles and rules of law derived from the study of literature relating to the object of research, namely the Judicial Commission, in order to obtain the answer to the problems formulated. From the research found an answer meant that the role of the Judicial Commission in the framework of the supervision of judges has not been effective. This is caused by having them do not have the authority to impose administrative punishment itself against judges and has no investigative authority of the judges who proved in a criminal investigation against the rules.

Keywords: monitoring, investigation, recommendation, punishment

\begin{abstract}
Abstrak
Tulisan ini dibuat untuk mengetahui efektivitas Komisi Yudisial dalam pengawasan terhadap hakim di Indonesia dan penyebab hal tersebut. Kasuskasus penindakan hakim yang melanggar kode etik hakim maupun melanggar hukum sudah menjadi fenomena saat ini. Metode penelitian yang digunakan dalam tulisan ini adalah "penelitian hukum normatiflyuridis normatif, data yang diperoleh dianalisis secara deskriptif kualitatif. Analisis deskriptif kualitatif yaitu metode analisis data yang mengelompokkan dan menyeleksi data primer berupa undang-undang, kemudian dihubungkan dengan teoriteori, asas-asas, dan kaidah-kaidah hukum yang diperoleh dari studi kepustakaan yang berkaitan dengan obyek penelitian yaitu Komisi Yudisial, sehingga diperoleh jawaban atas permasalahan yang dirumuskan. Dari hasil penelitian dimaksud ditemukan jawaban bahwa peran Komisi Yudisial dalam rangka pengawasan terhadap para hakim belum efektif. Hal ini disebabkan oleh karena diantaranya tidak mempunyai kewenangan untuk menjatuhkan hukuman administrasi sendiri terhadap hakim dan tidak mempunyai kewenangan penyidikan terhadap para hakim yang terbukti di dalam pemeriksaan melanggar aturan pidana.
\end{abstract}

Kata kunci: pengawasan, penyidikan, rekomendasi, penghukuman

${ }^{1}$ Penulis adalah Staf Pengajar pada Fakultas Hukum Universitas Pasundan. Alamat kontak: wahyuwiriadinata@yahoo.co.id. 


\section{Pendahuluan}

Kemandirian peradilan di Indonesia dijamin oleh Undang-Undang Dasar 1945. Pada Pasal 24 ayat (1) disebutkan bahwa:

Kekuasaan Kehakiman adalah merupakan kekuasaan yang merdeka untuk menyelenggarakan peradilan guna menegakkan hukum dan keadilan.

Demikian juga dalam Undang-Undang Nomor 48 Tahun 2009 tentang Kekuasaan Kehakiman, pasal 1 ayat (1) dinyatakan bahwa:

Kekuasaan Kehakiman adalah kekuasaan negara yang merdeka untuk menyelenggarakan peradilan guna menegakkan hukum dan keadilan berdasarkan Pancasila dan Undang-Undang Dasar Negara Republik Indonesia Tahun 1945 demi terselenggaranya Negara Hukum Republik Indonesia.

Ini mengandung suatu arti bahwa kekuasaan kehakiman adalah suatu lembaga yang harus lepas dan bebas dari pengaruh kekuasaan legislatif, eksekutif maupun kekuasaan lainnya.

Kemerdekaan hakim sangat berkaitan erat dengan sikap tidak berpihak atau sikap imparsial hakim, baik dalam pemeriksaan maupun dalam pengambilan keputusan. Hakim yang tidak independen tidak dapat diharapkan bersikap netral atau imparsial dalam menjalankan tugasnya. Demikian pula lembaga peradilan yang tergantung pada organ lain dalam bidang tertentu dan tidak mampu mengatur dirinya secara mandiri juga akan menyebabkan sikap yang tidak netral dalam menjalankan tugasnya. Kemerdekaan tersebut juga memiliki aspek yang berbeda. Kemerdekaan fungsional, mengandung larangan bagi cabang kekuasaan yang lain untuk mengadakan intervensi terhadap hakim dalam melaksanakan tugas justisialnya.

Implementasi kemandirian hakim dan peradilan sesungguhnya dibatasi terutama oleh aturan-aturan hukum itu sendiri. Ketentuan-ketentuan hukum, baik segi prosedural maupun substansial atau materiil merupakan batasan bagi kekuasaan kehakiman agar dalam melakukan independensinya dan tidak melanggar hukum serta bertindak sewenang-wenang. Hakim adalah "subordinated" pada Hukum dan tidak dapat bertindak "contra legem". Selanjutnya harus disadari bahwa kebebasan dan independensi tersebut diikat pula dengan pertanggungjawaban atau akuntabilitas. Di mana keduanya pada dasarnya merupakan dua sisi koin mata uang yang sama. Tidak ada kebebasan mutlak tanpa tanggung jawab. Dengan perkataan lain dapat dipahami bahwa dalam konteks kebebasan hakim haruslah diimbangi dengan pasangannya yaitu akuntabilitas peradilan (judicial accountability). ${ }^{2}$

2 Mukhlas, Integritas dan Profesionalitas Korps Penegak Hukum di Indonesia, Makalah, Bandung, tanpa tanggal dan tahun, hal. 1. 
Diperlukan hakim yang jujur dan tidak koruptif. Perlu pengawasan yang obyektif untuk mengontrol tugasnya. Lembaga itu telah ada yaitu Komisi Yudisial di samping lembaga fungsional yaitu Mahkamah Agung. Akan tetapi kenyataannya banyak kasus perilaku hakim yang menyimpang dari apa yang seharusnya beberapa contoh, yaitu kasus Hakim Syarifudin yaitu Hakim Pengawas di Pengadilan Negeri di Jakarta Pusat yang ditangkap oleh Komisi Pemberantasan Korupsi karena menerima suap dari Kurator Puguh Iriawan. Kasus tersebut telah menjadi perkara Tindak Pidana Korupsi dan Hakim Syarifudin telah divonis 4 tahun penjara sedangkan Puguh Iriawan divonis 3 tahun 8 bulan penjara. Dalam tahap upaya hukum.

Juga Hakim Imas Dianasari yaitu Hakim Ad Hoc Pengadilan Hubungan Industri di Pengadilan Negeri Bandung, ditangkap Komisi Pemberantasan Korupsi karena menerima suap. Perkaranya telah diputus di Pengadilan Tindak Pidana Korupsi Bandung dan Hakim Imas divonis dengan hukuman penjara selama 6 tahun.

Selanjutnya di Semarang kasus Hakim Kartini Juliana Mandalena Marpaung dan Hakim Heri Kusbandono disidik oleh Komisi Pemberantasan Korupsi, karena disangka telah melakukan tindak pidana korupsi dan perkaranya sedang disidangkan. Perkara ini juga melibatkan hakim dan pihak lain, Ketua Dewan Perwakilan Rakyat Daerah (non aktif) Grobogan Jawa Tengah Muhammad Yaeni, di Pengadilan Tindak Pidana Korupsi Semarang. Para pihak yang terlibat dalam perkara di atas antara lain Sutjahjo Padmo Wasono, Ketua Pengadilan Negeri Semarang merangkap Ketua Pengadilan Tipikor Semarang yang mendistribusikan perkara Yaeni ke tim Kartini dan pernah bertemu dengan Henu Kusbandono untuk membahas majelis perkara Yaeni, serta menolak merombak tim Kartini yang menangani kasus Yaeni.

Pragsono Hakim karier Pengadilan Negeri Semarang yang bersertifikat Hakim Tipikor, Ketua Majelis perkara Yaeni menggantikan Lilik Nuraini, yang dipindah ke Tondano, Sulawesi Utara, diduga aktif berhubangan dengan Heru untuk mengatur perkara Yaeni serta diduga aktif meminta uang ke Heru.

Kartini Juliana Mandalena Marpaung Hakim Ad Hoc Pengadilan Tipikor Semarang dari jalur pengacara yang ditangkap Komisi Pemberantasan Korupsi, aktif bertemu dengan Heru untuk mengatur vonis Yaeni, ditugaskan Pragsono menerima duit dari Yaeni melalui Heru, bakal menerima jatah suap dari Yaeni, bersama Lilik dan Asmadinata menjadi majelis hakim yang kerap membebaskan koruptor di Semarang dan sejak 9 Agustus lalu seharusnya sudah pindah ke Pengadilan Negeri Gorontalo karena terbukti melanggar kode etik hakim.

Asmadinata Hakim Ad Hoc Pengadilan Korupsi Semarang dari jalur pengacara bertemu dengan Heru untuk mengatur vonis Yaeni, kemudian diduga bakal menerima jatah suap dari Yaeni dan bersama Lilik dan Kartini menjadi Majelis Hakim yang kerap memvonis bebas koruptor di Semarang, sejak 9 Agustus lalu seharusnya sudah pindah ke Pengadilan Negeri Ambon karena terbukti melanggar kode etik hakim.

Lilik Nuraini sebelum dipindah ke Pengadilan Negeri Tondano dan digantikan Pragsono, ia Ketua Majelis perkara Yaeni, diduga terlibat mengatur 
perkara Yaeni sejak awal dan berhubungan dengan Heru lewat kartini, lalu dimutasi karena terbukti melanggar Kode Etik Hakim.

Heru Kusbandono Hakim Ad Hoc Pengadilan Korupsi Pontianak dari jalur pengacara, tersangka ditangkap Komisi Pemberantasan Korupsi yang menjadi makelar Yaeni ke Hakim Pengadilan Tipikor Semarang kerap datang ke Pengadilan Tipikor Semarang untuk mengatur kasus Yaeni yang berperan mengantar uang suap Yaeni ke Kartini.

Muhammad Yaeni Ketua DPRD nonaktif Grobogan yang menjadi terdakwa di Pengadilan Tipikor Semarang, yang meminta Heru melobi hakim Pengadilan Tipikor Semarang yang menangani perkaranya dan diduga yang menyuruh Sri Dartuti, adiknya, menyediakan uang suap.

Sri Dartuti Pengusaha di Semarang yang juga adik Yaeni diduga yang menyediakan dana suap.

Hakim-hakim dan pihak tersebut di atas diduga terlibat kasus penyuapan oleh Sri Dartuti kepada Hakim Tindak Pidana Korupsi Semarang. Perkaranya disidik oleh Komisi Pemberantasan Korupsi dan sedang diproses di Pengadilan Negeri Semarang.

Last but not lease kasus hakim yang menyalahgunakan narkotika yaitu dengan memakai dan pesta narkotika. Hal ini dilakukan oleh seorang hakim Pengadilan Negeri Bekasi berinisial PW yang ditangkap oleh aparat Badan Narkotika Nasional (BNN) pada 16 Oktober 2012 di sebuah tempat hiburan kawasan Jalan Hayam Wuruk Jakarta yang sedang berpesta narkoba bersama dengan tiga perempuan yang mendampingi hakim tersebut. Bersamaan dengan penangkapan itu disita pula barang bukti berupa ekstasi dan sabu-sabu.

Kasus-kasus di atas yang melibatkan hakim sebagai tersangka perkara korupsi dan penyalahgunaan narkoba, hanya sebagian kecil dari sekian banyak kasus korupsi dan tindak pidana lainnya serta pelanggaran kode etik hakim yang dilakukan oleh hakim. Padahal Undang-Undang Nomor 22 Tahun 2004 tentang Komisi Yudisial telah ada sejak tahun 2004.

Dari uraian tersebut di atas muncul pertanyaan dan masalah yang perlu dilakukan pengkajian yaitu:

\section{Bagaimana efektivitas dari lembaga Komisi Yudisial di dalam rangka pengawasan terhadap perilaku hakim dan menanggulangi perilaku hakim yang negatif serta apa penyebab dari kurang efektifnya lembaga Komisi Yudisial di dalam pengawasan terhadap perilaku hakim dan penanggulangan perilaku hakim yang negatif.}

Untuk mengurai pertanyaan di atas dan menjawab permasalahan yang telah dirumuskan, digunakan metode penelitian, yaitu penelitian hukum normatif/yuridis normatif, data yang diperoleh dianalisis secara deskriptif kualitatif. Analisis deskriptif kualitatif yaitu metode analisis data yang mengelompokkan dan menyeleksi data primer berupa undang-undang, kemudian dihubungkan dengan teori-teori, asas-asas, dan kaidah-kaidah hukum yang diperoleh dari studi kepustakaan sehingga diperoleh jawaban atas permasalahan yang dirumuskan. 
Adapun guna tulisan ini ialah mudah-mudahan berguna bagi dunia ilmu pengetahuan hukum pada khususnya dan ilmu pengetahuan pada umumnya.

\section{Landasan Pemikiran}

Tulisan ini dilandasi oleh pemikiran, bahwa tujuan hukum untuk mencapai keadilan di masyarakat merupakan tujuan hukum yang utama. Selain untuk tercapainya kepastian hukum sebagaimana dimaksud oleh aliran Rechts Positivisme yang dipelopori oleh Hans Kelsen. Tujuan hukum untuk mencapai keadilan merupakan tujuan hukum yang paling tua yang sampai saat ini tetap dipertahankan. Namun dengan syarat bahwa di masyarakat harus terlebih dahulu terciptanya ketertiban.

Tentang hal tersebut di atas dikemukakan juga oleh Muchtar Kusumaatmadja yang memberikan definisi hukum, yaitu:

Hukum adalah keseluruhan asas dan kaidah yang mengatur pergaulan hidup manusia dalam masyarakat yang bertujuan untuk memelihara ketertiban dan mencapai keadilan, juga meliputi lembaga serta proses yang mewujudkan berlakunya kaidah tersebut sebagai kenyataan di masyarakat. $^{3}$

Dari definisi yang dikemukakan tersebut di atas, jelaskan bahwa menurut Muchtar Kusumaatmadja tujuan hukum yang hakiki ialah terpeliharanya ketertiban dan tercapainya keadilan. Pemikiran dari Muchtar Kusumaatmadja ini sejalan dengan pemikiran Roscoe Pound ${ }^{4}$ Lebih jauh lagi Roscoe Pound mengemukakan tentang hukum sebagai alat pembaharuan masyarakat: Law as a tool of social engineering, hukum sebagai alat pembaharuan masyarakat. Konsep ini dilansir oleh Muchtar Kusumaatmadja disesuaikan dengan kondisi Indonesia menjadi hukum sebagai sarana pembaharuan masyarakat. Pembaharuan maksudnya ialah memperbaharui cara berfikir masyarakat dari cara berfikir tradisional kepada cara berfikir modern. Hukum harus bisa dijadikan sarana untuk memecahkan semua problem yang ada di dalam masyarakat. Konkritnya dalam konteks tulisan ini, bahwa problema hukum juga harus bisa menjawab masalah penyimpangan perilaku hakim di dalam pelaksanaan tugas penegakan hukum, sebab banyak hakim yang melakukan tindak pidana korupsi pada waktu melaksanakan tugasnya. Untuk mengurai problem tersebut salah satu hal yang harus diperbaharui adalah sistem hukum sebagaimana yang termuat di dalam undang-undang tentang komisi yudisial, khususnya mengenai pengawasan terhadap hakim. Dimana tidak mengatur tentang kewenangan Komisi Yudisial yang mempunyai otoritas untuk

${ }^{2}$ P. Sitorus, "Pengantar Ilmu Hukum (Dilengkapi Tanya Jawab)", Pasundan Law Faculty, (Bandung: Alumnus Press, 1998), hal. 94.

\footnotetext{
${ }^{4}$ Roscoe Pound, Pengantar Filsafat Hukum, (Jakarta: Bharata, 1972), hal. 37.
} 
menjatuhkan hukuman terhadap hakim, Komisi Yudisial hanya bisa memberikan rekomendasi kepada Mahkamah Agung atau Mahkamah Konstitusi untuk menjatuhi hukuman kepada hakim dari hasil pemeriksaan Komisi Yusidial. Juga upaya paksa dalam pembuktian dan norma-norma lain yang bersifat dapat membuat jera para hakim, termasuk melakukan penyidikan terhadap hakim yang melakukan perbuatan tindak pidana seperti korupsi dan tindak pidana lainnya. Hal itu tidak bisa dilakukan oleh Komisi Yudisial karena memang dalam Undang-Undang Komisi Yudisial kewenangan itu tidak ada.

\section{Pembahasan}

\section{Hakim dan Pengadilan}

Hakim adalah pejabat negara yang melakukan kekuasaan kehakiman yang diatur dalam Undang-undang. ${ }^{5}$ Sebagai pejabat negara yang melakukan kekuasaan kehakiman, ia harus memiliki integritas dan kepribadian yang tidak tercela, jujur, adil, profesional dan berpengalaman di bidang hukum. Dalam menjalankan tugas dan fungsinya, hakim wajib menjaga kemandirian peradilan.

Dari ketentuan-ketentuan tersebut dapat dirinci bahwa unsur-unsur hakim yang baik itu adalah hakim yang memiliki: integritas, kepribadian, jujur, adil, profesional, berpengalaman dan menjaga kemandirian peradilan.

Berkenaan dengan pengharapan dan upaya mendapatkan hakim yang baik, yang memiliki integritas dan profesional itu diperlukan komitmen lembaga terkait yang memiliki wewenang untuk merekrut dan menyeleksi hakim, yakni dengan mengedepankan prinsip-prinsip transparansi, partisipasi, akuntabilitas, right man on the right place dan objektif.

Integritas dapat dimaknakan dengan "suatu sifat, mutu atas keadaan yang menunjukkan kesatuan yang utuh sehingga memiliki potensi dan kemampuan yang memancarkan kewibawaan dan kejujuran". 6 Dalam pandangan Komisi Yudisial, prinsip integritas itu sebagai sikap dan kepribadian yang utuh, berwibawa, jujur dan tidak tergoyahkan. Dalam konteks jabatan hakim selaku pejabat negara yang ditugasi menegakkan hukum dan keadilan, unsur integritas calon hakim itu dapat diperoleh melalui rekrutmen dan seleksi yang ketat dan baik. Namun demikian, integritas itu harus dipupuk dan dikembangkan secara berkelanjutan melalui pendidikan dan latihan. Jika seorang hakim memiliki integritas, dengan sendirinya ia memiliki potensi, dan kemampuan yang pada akhirnya akan melahirkan kewibawaan dan kejujuran.

${ }^{5}$ Pasal 31 Undang-undang Nomor 4 Tahun 2004 tentang Kekuasaan Kehakiman.

${ }^{6}$ Lihat Kamus Umum Bahasa Indonesia Edisi ke 3, (Jakarta: Balai Pustaka) hlm. 347. 
Di Indonesia jabatan hakim sebagai suatu profesi, memiliki kode etik yaitu Keputusan Bersama Ketua Mahkamah Agung Republik Indonesia dan Ketua Komisi Yudisial Republik Indonesia Nomor 047/KMA/SKB/IV/ 2009 dan 02/SKB/P.KY/IV.2009 tentang Kode Etik dan Pedoman Perilaku Hakim yang harus dijadikan dasar perilaku dan tindakan profesi hakim. Kode etik tersebut dirumuskan dengan maksud untuk melakukan pembinaan dan pembentukan karakter serta untuk mengawasi tingkah laku hakim. Dengan demikian jika karakter telah terbentuk dan perilaku hakim didasarkan pada patokan, diharapkan akan menumbuhkan kepercayaan masyarakat pada lembaga peradilan. ${ }^{7}$ Dalam upaya mengawal penegakkan hukum yang bersih dan berkeadilan, Komisi Yudisial telah berhasil membuat rancangan dan mendorong terwujudnya Pedoman Etika Perilaku Hakim, yang didasarkan pada The Bangalore Principle of Judicial Conduct.

Pedoman Perilaku Hakim yang dirancang Komisi Yudisial tersebut merupakan sumbangan besar kepada Mahkamah Agung. Pengembangan prinsip integritas hakim sebagai salah satu unsur dari Pedoman Perilaku Hakim itu perlu dilakukan secara terus menerus dan berkelanjutan. Pengembangan prinsip integritas hakim itu antara lain berbunyi: hakim berperilaku tidak tercela; menghindari konflik kepentingan; mengundurkan diri jika terjadi konflik kepentingan; dan menghindari pemberian hadiah dari pemerintah daerah walaupun pemberian tersebut tidak mempengaruhi tugas-tugas yudisial.

Mahkamah Agung selaku lembaga peradilan tertinggi di Indonesia telah mengapresiasi prinsip integritas hakim ini dan mengembangkanya menjadi 17 (tujuh belas) butir perilaku hakim. Prinsip utama dari pengembangan itu agar hakim mempunyai kepribadian untuk tidak tergoyahkan, berani menolak godaan dan intervensi. dan selalu berusaha melaksanakan tugas dengan cara-cara terbaik untuk mencapai tujuan yang baik. Butir-butir itu kemudian menjadi rambu-rambu bagi perilaku hakim, yaitu sebagai berikut:

\section{Mempunyai Rasa Keadilan}

Adil mengandung arti "menempatkan sesuatu pada tempatnya" dan memberikan sesuatu yang menjadi haknya, yang didasarkan atas suatu prinsip, bahwa semua orang sama kedudukannya di depan hukum. Tuntutan yang paling mendasar dari keadilan adalah memberikan perlakuan dan memberi kesempatan yang sama (equality and fairness) terhadap setiap orang. Karena itu, seseorang yang melaksanakan tugas atau profesi di bidang peradilan yang memikul tanggung jawab menegakkan hukum yang adil dan benar harus selalu berlaku adil dengan tidak membeda-bedakan orang. Dalam lingkungan peradilan, keharusan

\footnotetext{
${ }^{7}$ Lihat Wildan Suyuthi, "Kode Etik Hakim, dalam Pedoman Perilaku Hakim (Code of Conduct)", (Jakarta: Mahkamah Agung Republik Indonesia, 2003), hal. 33.
} 
perlakuan adil itu lebih banyak dibebankan kepada sosok hakim, karena dalam proses persidangan, para hakim itu merupakan pemeran utama untuk memeriksa dan mengadili perkara para pihak.

\section{Jujur}

Ini mengandung makna, dapat dan berani menyatakan bahwa yang benar adalah benar dan yang salah adalah salah. Kejujuran mendorong terbentuknya pribadi yang kuat dan membangkitkan kesadaran akan hakikat yang hak dan yang bathil. Dengan demikian, akan terwujud sikap pribadi yang tidak berpihak terhadap setiap orang baik dalam persidangan maupun di luar persidangan.

\section{Arif dan Bijaksana}

Hakikatnya adalah mampu bertindak sesuai dengan norma-norma yang hidup dalam masyarakat, baik norma-norma hukum, norma-norma keagamaan, kebiasaan-kebiasaan maupun kesusilaan dengan memperhatikan situasi dan kondisi pada saat itu, serta mampu memperhitungkan akibat dari tindakannya itu. Perilaku yang arif dan bijaksana mendorong terbentuknya pribadi yang berwawasan luas, mempunyai tenggang rasa yang tinggi, bersikap hati-hati, sabar dan santun. Karena itu, dalam konteks tertentu perilaku Hakim dibatasi, yakni dalam hal:

\section{Mandiri}

Adanya independensi yang mampu bertindak sendiri tanpa bantuan pihak lain, bebas dari campur tangan siapapun (eksekutif dan legislatif) dan bebas dari pengaruh apa pun. Sikap mandiri mendorong terbentuknya perilaku hakim yang tangguh, berpegang teguh pada prinsip dan keyakinan atas kebenaran sesuai tuntutan moral dan ketentuan hukum yang berlaku. Ketentuan itu menunjukkan bahwa hakim harus menjalankan fungsi peradilan secara mandiri dan bebas dari pengaruh, tekanan, ancaman atau bujukan, baik yang bersifat langsung maupun tidak langsung dari pihak manapun.

\section{Berintegritas Tinggi}

Ini mengandung makna mempunyai kepribadian utuh, tidak tergoyahkan, yang terwujud pada sikap setia dan tangguh berpegang pada nilai-nilai atau norma-norma yang berlaku dalam melaksanakan tugas. Integritas tinggi akan mendorong terbentuknya pribadi yang berani menolak godaan dan segala bentuk intervensi, dengan mengendapkan tuntutan hati nurani untuk menegakkan kebenaran dan keadilan. dan selalu berusaha melakukan tugas dengan cara-cara terbaik untuk mencapai tujuan yang lebih baik. 


\section{Bertanggungjawab}

Arti dari tanggung jawab adalah kesediaan dan keberanian untuk melaksanakan semua tugas dan wewenang sebaik mungkin serta bersedia menanggung segala akibat atas pelaksanaan tugas dan wewenangnya itu. Rasa tanggung jawab akan mendorong terbentuknya pribadi yang mampu menegakkan kebenaran dan keadilan, penuh pengabdian, serta tidak menyalahgunakan profesi yang diamanatkan.

\section{Menjunjung Tinggi Harga Diri}

Hakikat dari menunjunjung tinggi harga diri adalah bahwa pada diri manusia melekat martabat dan kehormatan yang harus dipertahankan dan dijunjung tinggi. Prinsip menjunjung tinggi harga diri, khususnya Hakim, akan mendorong dan membentuk pribadi yang kuat dan tangguh, sehingga terbentuk pribadi yang senantiasa menjaga kehormatan dan martabatnya sebagai aparatur peradilan.

\section{Berdisiplin Tinggi}

Ini mengandung arti ketaatan pada norma-norma atau kaidah-kaidah yang diyakini sebagai panggilan luhur untuk mengemban amanah serta kepercayaan masyarakat pencari keadilan. Disiplin tinggi akan mendorong terbentuknya pribadi yang tertib di dalam melaksanakan tugas, ikhlas dalam pengabdian, dan berusaha untuk menjadi teladan dalam lingkungannya, serta tidak menyalahgunakan amanah yang dipercayakan kepadanya.

\section{Rendah Hati}

Hakikatnya yaitu berupa kesadaran akan keterbatasan kemampuan diri, jauh dari kesempurnaan dan terhindar dari setiap bentuk keangkuhan. Rendah hati akan mendorong terbentuknya sikap realistis, mau membuka diri untuk terus belajar, menghargai pendapat orang lain, menumbuh kembangkan sikap tenggang rasa, serta mewujudkan kesederhanaan, penuh rasa syukur dan ikhlas di dalam mengemban tugas.

\section{Profesional}

Hakikat profesional yaitu sikap moral yang dilandasi oleh tekad untuk melaksanakan pekerjaan yang dipilihnya dengan kesungguhan, yang didukung oleh keahlian atas dasar pengetahuan. keterampilan dan wawasan luas. Sikap profesional akan mendorong terbentuknya pribadi yang senantiasa menjaga dan mempertahankan mutu pekerjaan, serta berusaha untuk meningkatkan pengetahuan dan kinerja, sehingga tercapai setinggi-tingginya mutu hasil pekerjaan, efektif dan efisien. 


\section{Profesionalitas Hakim}

Pengembangan profesionalitas hakim paling tidak dipengaruhi oleh dua hal, yaitu: (a) model pendidikan dan latihan dan (b) sistem pendidikan hakim secara umum. Pendidikan tinggi hukum di Indonesia yang menganut civil law, menghasilkan produk yang memiliki kesenjangan dengan kualifikasi di level praktis. Walaupun dari segi regulasi, lembaga-lembaga pendidikan hukum itu telah mengalami banyak kemajuan, yakni dengan penyempurnaan kurikulum serta masuknya mata-mata kuliah pendukung, tetapi hal itu belum dapat menjamin keluaran yang profesional dan siap pakai.

Di dalam kenyataannya apa yang terurai di atas yang secara umum merupakan hal yang tersurat dan termuat dalam Kode Etik dan Pedoman Perilaku Hakim dimana sosok hakim yang ideal nyatanya belum terbentuk, tercapai dan terpenuhi. Ini terindikasi dengan banyaknya kasus-kasus penyimpangan yang dilakukan oleh para hakim seperti digambarkan pada awal tulisan ini.

Akan tetapi kasus-kasus penyimpangan profesi hakim seperti tersebut di atas bukan merupakan keadaan hakim hari ini pada umumnya, sebab masih banyak kebaikan yang ada, berupa kinerja para hakim yang tinggi, dimana masih banyak hakim yang baik dan berdedikasi baik serta idealis. Begitu pula kinerja Komisi Yudisial yang telah tercapai di dalam pengawasan terhadap hakim dan menjaga kehormatan serta harkat derajat hakim, hal ini sudah banyak yang berhasil, diantaranya kenaikan gaji dan tunjangan hakim yang lebih tinggi dari sekarang. Hal ini akan menambah kesejahteraan para hakim yang akan mendukung naiknya citra hakim di hadapan keadilan dan masyarakat. Ini merupakan keberhasilan Komisi Yudisial dalam rangka tugas mengupayakan peningkatan kapasitas dan kesejahteraan hakim.

\section{Eksistensi Komisi Yudisial}

Komisi Yudisial merupakan lembaga negara yang bersifat mandiri dimana dalam pelaksanaan wewenangnya bebas dari campur tangan atau pengaruh kekuasaan eksekutif, legislatif dan kekuasaan lainnya. Berkedudukan di Ibukota Negara Republik Indonesia, yaitu Jakarta. Dalam memutar roda organisasinya digerakkan oleh pimpinan dan anggota, terdiri atas seorang Ketua dan seorang Wakil Ketua yang merangkap anggota, jumlahnya tujuh orang anggota yang berstatus sebagai pejabat negara. Keanggotaan Komisi Yudisial terdiri atas mantan hakim, praktisi hukum, akademisi hukum dan anggota masyarakat.

Kedudukan protokoler dan hak keuangan Ketua, Wakil Ketua, dan Anggota Komisi Yudisial diberlakukan ketentuan peraturan perundangundangan bagi pejabat negara. Anggaran Komisi Yudisial dibebankan pada Anggaran Pendapat dan Belanja Negara. 
Anggota Komisi Yudisial mempunyai forum previlegiatum, dimana anggota Komisi Yudisial dapat ditangkap atau ditahan hanya atas perintah Jaksa Agung setelah mendapat persetujuan Presiden, kecuali dalam hal: tertangkap tangan melakukan tindak pidana kejahatan, atau berdasarkan bukti permulaan yang cukup disangkal telah melakukan tindak pidana kejahatan yang diancam dengan pidana mati atau tindak pidana kejahatan terhadap keamanan. Pelaksanaan penangkapan atau penahanan sebagaimana dimaksud pada ayat (1) dalam waktu paling lama dua kali dua puluh empat jam harus dilaporkan kepada Jaksa Agung.

Adapun kewenangan Komisi Yudisial adalah: mengusulkan pengangkatan Hakim Agung kepada DPR dan menegakkan kehormatan dan keluhuran martabat serta menjaga perilaku hakim. Dalam melaksanakan kewenangan dimaksud Komisi Yudisial mempunyai tugas: melakukan pendaftaran calon Hakim Agung, melakukan seleksi terhadap calon Hakim Agung, menetapkan calon Hakim Agung dan mengajukan calon Hakim Agung ke DPR.

Komisi Yudisial juga mempunyai kewenangan dan tugas untuk melaksanakan pengawasan terhadap Hakim Mahkamah Agung, untuk itu bisa : menerima laporan masyarakat tentang perilaku hakim, meminta laporan secara berkala kepada badan peradilan berkaitan dengan perilaku hakim, melakukan pemeriksaan terhadap dugaan pelanggaran perilaku hakim, memanggil dan meminta keterangan dari hakim yang diduga melanggar kode etik perilaku hakim, dan membuat laporan hasil pemeriksaan yang berupa rekomendasi dan disampaikan kepada Mahkamah Agung dan/atau Mahkamah Konstitusi, serta tindasannya disampaikan kepada Presiden dan DPR, untuk itu mempunyai kewajiban: menaati norma, hukum, dan ketentuan peraturan perundangundangan; dan menjaga kerahasiaan keterangan yang karena sifatnya merupakan rahasia Komisi Yudisial yang diperoleh berdasarkan kedudukannya sebagai anggota.

Badan peradilan dan hakim wajib memberikan keterangan atau data yang diminta Komisi Yudisial dalam rangka pengawasan terhadap perilaku hakim dalam jangka waktu paling lambat 14 (empat belas) hari terhitung sejak tanggal permintaan Komisi Yudisial diterima. Semua keterangan dan data sebagaimana dimaksud pada ayat (4) bersifat rahasia.

Untuk dapat diangkat menjadi Anggota Komisi Yudisial harus memenuhi syarat : Warga Negara Indonesia, bertaqwa kepada Tuhan Yang Maha Esa, berusia paling rendah empat puluh tahun dan paling tinggi enam puluh delapan tahun pada saat proses pemilihan, mempunyai pengalaman di bidang hukum paling singkat lima belas tahun, memiliki integritas dan kepribadian yang tidak tercela, sehat jasmani dan rohani, tidak pernah dijatuhi pidana karena melakukan tindak pidana kejahatan, dan melaporkan daftar kekayaan.

Anggota Komisi Yudisial yang terpilih diangkat oleh Presiden dan dengan persetujuan DPR, Komisi Yudisial bertanggung jawab kepada publik melalui DPR.

Kewenangan Komisi Yudisial adalah: mengusulkan pengangkatan Hakim Agung dan Hakim ad hoc di Mahkamah Agung kepada DPR untuk 
mendapatkan persetujuan, menjaga dan menegakkan kehormatan, keluhuran martabat, serta perilaku hakim, menetapkan Kode Etik dan/atau Pedoman Perilaku Hakim bersama-sama dengan Mahkamah Agung, dan menjaga dan menegakkan pelaksanaan Kode Etik dan/atau Pedoman Perilaku Hakim.

Dalam rangka menjaga dan menegakkan kehormatan, keluhuran martabat, serta perilaku Hakim di atas Komisi Yudisial mempunyai tugas: melakukan pemantauan dan pengawasan terhadap perilaku Hakim, menerima laporan dari masyarakat berkaitan dengan pelanggaran Kode Etik dan/atau Pedoman Perilaku Hakim, melakukan verifikasi, klarifikasi, dan investigasi terhadap laporan dugaan pelanggaran Kode Etik dan/atau Pedoman Perilaku Hakim secara tertutup, memutuskan benar tidaknya laporan dugaan pelanggaran Kode Etik dan/atau Pedoman Perilaku Hakim, dan mengambil langkah hukum dan/atau langkah lain terhadap orang perseorangan, kelompok orang, atau badan hukum yang merendahkan kehormatan dan keluhuran martabat Hakim.

Selain itu Komisi Yudisial juga mempunyai tugas mengupayakan peningkatan kapasitas dan kesejahteraan Hakim.

Dalam melakukan pengawasan Hakim, Komisi Yudisial menerima laporan masyarakat dan/atau informasi tentang dugaan perilaku pelanggaran Kode Etik dan/atau Pedoman Perilaku Hakim. Untuk melaksanakan pengawasan itu Komisi Yudisial dapat meminta keterangan atau data kepada Badan Peradilan dan/atau Hakim.

Pimpinan Badan Peradilan dan/atau Hakim wajib memberikan keterangan atau data yang diminta oleh Komisi Yudisial sebagaimana dimaksud.

Dalam pelaksanaan tugas dimaksud di atas Komisi Yudisial dapat : melakukan verifikasi terhadap laporan, melakukan pemeriksaan atas dugaan pelanggaran, melakukan pemanggilan dan meminta keterangan dari Hakim yang diduga melanggar pedoman kehormatan, keluhuran martabat, serta perilaku Hakim untuk kepentingan pemeriksaan, melakukan pemanggilan dan meminta keterangan dari saksi, dan menyimpulkan hasil pemeriksaan.

Pemeriksaan oleh Komisi Yudisial meliputi : pemeriksaan terhadap dugaan pelanggaran Kode Etik dan/atau Pedoman Perilaku Hakim dan permintaan klarifikasi terhadap Hakim yang diduga melakukan pelanggaran sebagaimana dimaksud di atas.

Dalam setiap pemeriksaan sebagaimana dimaksud dibuatkan berita acara pemeriksaan yang disyahkan dan ditandatangani oleh terperiksa dan pemeriksa.

Klarifikasi sebagaimana dimaksud, diajukan oleh hakim yang diduga melakukan pelanggaran dalam jangka waktu paling lama 14 (empat belas) hari sejak diterimanya pemanggilan yang menyebutkan adanya dugaan pelanggaran Kode Etik dan/atau Pedoman Perilaku Hakim secara patut oleh Komisi Yudisial.

Hasil pemeriksaan atas dugaan pelanggaran Kode Etik dan/atau Pedoman Perilaku Hakim berisi : dugaan pelanggaran dinyatakan terbukti, atau dugaan pelanggaran dinyatakan tidak terbukti. 
Dalam hal dugaan pelanggaran Kode Etik dan/atau Pedoman Perilaku Hakim dinyatakan terbukti, Komisi Yudisial mengusulkan penjatuhan sanksi terhadap Hakim yang diduga melakukan pelanggaran kepada Mahkamah Agung sanksinya berupa: Sanksi ringan terdiri atas: teguran lisan, teguran tertulis, atau pernyataan tidak puas secara tertulis. Sanksi sedang terdiri atas : penundaan kenaikan gaji berkala paling lama 1 (satu) tahun, penurunan gaji sebesar 1 (satu) kali kenaikan gaji berkala paling lama 1 (satu) tahun, penundaan kenaikan pangkat paling lama 1 (satu) tahun, atau hakim nonpalu paling lama 6 (enam) bulan. Sanksi berat terdiri atas: pembebasan dari jabatan struktural, hakim nonpalu lebih dari 6 (enam) bulan sampai dengan 2 (dua) tahun, pemberhentian sementara, pemberhentian tetap dengan hak pensiun, atau pemberhentian tetap tidak dengan hormat.

Mahkamah Agung menjatuhkan sanksi terhadap Hakim yang melakukan pelanggaran Kode Etik dan/atau Pedoman Perilaku Hakim yang diusulkan oleh Komisi Yudisial dalam waktu paling lama 60 (enam puluh) hari terhitung sejak tanggal usulan diterima.

\section{Fakta Konkrit}

1. Di dalam Pasal 21 Undang-Undang Nomor 22 Tahun 2004 tentang Komisi Yudisial disebutkan bahwa:

Untuk kepentingan pelaksanaan kewenangan sebagaimana dimaksud Pasal 13 huruf $b^{, 8}$ Komisi Yudisial bertugas mengajukan usul menjatuhkan sanksi terhadap hakim kepada pimpinan Mahkamah Agung dan/atau Mahkamah Konstitusi.

Dari bunyi Pasal tersebut di atas bisa ditarik pengertian bahwa Komisi Yudisial hanya bisa mengajukan/merekomendasikan untuk memberi sanksi/menghukum (administrasi/disiplin) seorang hakim kepada pimpinan Mahkamah Agung dan/atau Mahkamah Konstitusi. Jadi Komisi Yudisial tidak boleh menjatuhkan hukuman sendiri kepada para hakim. Komisi Yudisial hanya dapat memeriksa kasus yang melibatkan seorang hakim, itu pun terbatas kepada perilaku hakim yang melanggar kode etik hakim, di luar pro justisia, yang normanya diatur dalam Kode Etik dan Pedoman Perilaku Hakim.

Sedangkan apabila ditemukan dan terbukti adanya perbuatan yang melanggar hukum pidana, maka Komisi Yudisial tidak dapat mengambil langkah lebih lanjut seperti kewenangan untuk penyidikan. Ini merupakan kelemahan yang ada di tubuh Komisi Yudisial.

\footnotetext{
${ }^{8}$ Pasal 13 huruf b Undang-Undang Nomor 21 Tahun 2004 tentang Komisi Yudisial berbunyi : "Komisi Yudisial berwenang, b: menegakkan kehormatan dan keluhuran martabat serta menjaga perilaku hakim".
} 
Terhadap usulan penjatahan hukuman administrasi oleh Komisi Yudisial kepada pimpinan Mahkamah Agung dan/atau Mahkamah Konstitusi, sikap Mahkamah Agung dan Mahkamah Konstitusi terhadap usulan Komisi Yudisial itu tidak otomatis harus dijalankan oleh Mahkamah Agung dan/atau Mahkamah Konstitusi. Akan tetapi bisa saja Mahkamah Agung dan Mahkamah Konstitusi tidak melaksanakan rekomendasi seperti yang direkomendasikan oleh Komisi Yudisial tersebut. Walau dalam prakteknya banyak juga usulan penjatahan hukuman terhadap hakim dari Komisi Yudisial yang diakomodir oleh pimpinan Mahkamah Agung.

Begitu juga terhadap hasil pemeriksaan Komisi Yudisial yang menemukan adanya unsur pidana dari perbuatan hakim, belum ada patron yang baku untuk tindakan selanjutnya yang dapat dilakukan oleh Komisi Yudisial.

Melihat kenyataan tersebut di atas, maka untuk itu di masa yang akan datang agar supaya peran Komisi Yudisial lebih menggigit, maka Komisi Yudisial harus diberi kewenangan tambahan yaitu kewenangan untuk menjatuhkan hukuman administrasi/disiplin sesuai dengan kode etik hakim. Di samping itu Komisi Yudisial harus diberi kewenangan pro justitia yaitu kewenangan untuk melakukan penyidikan terhadap para hakim yang diduga atau diindikasikan melakukan tindak pidana. Untuk kewenangan itu tentu harus didukung oleh perangkat perundangundangan yaitu dengan merubah Undang-Undang Nomor 22 Tahun 2004 tentang Komisi Yudisial, dengan menyisipkan pasal-pasal kewenangan penyidikan oleh Komisi Yudisial terhadap para hakim yang diduga melakukan tindak pidana.

1. Akibat dari ketidakpunyaan kewenangan dari Komisi Yudisial untuk menjatuhkan hukuman sendiri terhadap para hakim yang melakukan pelanggaran kode etik serta ketidakpunyaan kewenangan dari Komisi Yudisial untuk melakukan penyidikan terhadap para hakim yang diduga melakukan tindak pidana, hal ini menimbulkan peran Komisi Yudisial terhadap pengawasan para hakim menjadi kurang menggigit, akibatnya maka para hakim tidak mempunyai rasa jera di dalam melakukan perbuatan penyimpangan yang negatif, baik itu pelanggaran terhadap kode etik dan pedoman perilaku hakim maupun pelanggaran terhadap hukum pidana.

\section{Penutup}

\section{Kesimpulan}

Peran Komisi Yudisial dalam rangka pengawasan terhadap para hakim belum efektif, ini terindikasi dengan masih banyaknya para hakim yang melakukan pelanggaran, baik terhadap kode etik hakim maupun pelanggaran terhadap ketentuan pidana. 
Hal ini disebabkan oleh karena diantaranya ada kelemahan dalam regulasi yaitu tidak mempunyai kewenangan untuk menjatuhkan hukuman administrasi sendiri terhadap hakim yang melakukan pelanggaran Kode Etik dan Pedoman Perilaku Hakim, juga Komisi Yudisial tidak mempunyai kewenangan penyidikan terhadap para hakim yang terbukti di dalam pemeriksaan melanggar aturan pidana.

\section{Saran}

Supaya kepada Komisi Yudisial selain diberi kewenangan untuk memeriksa dan membuktikan adanya pelanggaran kode etik dan tindak pidana, juga Komisi Yudisial diberikan kewenangan untuk menghukum berdasarkan kode etik dan perilaku hakim serta diberikan kewenangan untuk melakukan penyidikan terhadap hakim yang 


\section{Daftar Pustaka}

Adji, Oemar Seno. Hukum (Acara) Pidana dalam Prospeksi, Jakarta: Erangga, 1976.

Hamzah, Andi. Hukum Acara Pidana Indonesia, Jakarta: Sinar Grafika, 2006.

Nawawi Arief, Barda. Bunga Rampai Kebijakan Hukum Pidana, Cetakan Kesatu, Bandung: Penerbit PT. Citra Aditya Bakti, 1996 .

Pound, Roscoe. Pengantar Filsafat Hukum, Jakarta. Bharata, 1972.

Prodjodikoro, Wirjono. Hukum Atjara Pidana di Indo, Bandung: Penerbit Sumur Bandung, 1967.

Sitorus, P. Pengantar Ilmu Hukum (dilengkapi tanya jawab), Pasundan Law Faculty, Bandung: Alumnus Press, 1998.

Soedjono D. Pemeriksaan Pendahuluan Menurut KUHAP, Bandung: Alumni, 1982.

Suyuthi, Wildan. "Kode Etik Hakim, dalam Pedoman Perilaku Hakim (Code of Conduct), Jakarta: Mahkamah Agung Republik Indonesia, 2003.

Tahir, Hadari Djenawi. Pokok-Pokok Pikian dalam KUHAP, Bandung: Alumni, 1981.

Tanusuboto, S. Peranan Praperadilan dalam Hukum Acara Pidana, Bandung: Alumni, 1983.

Tresna, R. Komentar HIR, Djakarta: Pradnya Paramita, tanpa tahun.

Undang-Undang Nomor 8 Tahun 1981, tentang Hukum Acara Pidana.

Undang-Undang Nomor 31 Tahun 1999, tentang Pemberantasan Tindak Pidana Korupsi.

Undang-Undang Nomor 21 Tahun 2011, tentang Otoritas Jasa Keuangan. 